\title{
Andrzej Rokicki
}

ORCID: htpp://orcid.org/000-0001-5074-0515

Andrzej Frycz Modrzewski Krakow University, Krakow, Poland

\section{The importance of physical and social activity in the process of positive aging}

\begin{abstract}
The article aims to draw attention to the importance of physical and social activity in the elderly. It emphasizes the need for the care of one's physical and intellectual condition. It also accentuates the fact that being needed in the family and maintaining a social life is crucial for each senior. The article also stresses the important role that Pope John Paul II fulfilled in intergenerational relations. Peaceful and happy aging is largely dependent on making young people and seniors aware that we must take care of our health in advance, and that it is never too late to be active
\end{abstract}

\section{Keywords}

Senior/elderly, physical activity, social activity, senility/senescence, health, positive aging.

Civilization, cultural and economic changes, technological progress and behaviours in the moral sphere which differ from those known so far, have brought a change in intergenerational relations from the previous, traditional understanding. A dozen or so years ago, these relations were based on respect and hierarchy stemming from age and acquired knowledge. They were deeply rooted in the life of a multi-generational family. However, at the beginning of the 21st century, in Poland - as in most other European countries - the disappearance of multi-generational families is noticeable. This process has a large impact 
on the diminishing contact between the elderly and the young generation. As a result, stereotypes and negative attitudes towards both the elderly and young people may develop.

Therefore, one of the most surprising and important phenomena at the turn of the 2oth and 21st centuries was drawing old age and youth together, which was achieved thanks to the Polish Pope John Paul II. In the Letter of the Holy Father, "To my brothers and sisters - elderly people," he wrote: "it is imperative that we again look at life as a whole from the right perspective. Eternity is the right perspective, and each stage of life is an important preparation for it. Senility also has a role to play in this process of gradual maturation of a man on his way to eternity. From this maturation, the social environment, to which the elderly belongs, obviously also benefits. Old people help us to look at earthly events more wisely, because, thanks to their life experience, they have gained knowledge and maturity. They are the keepers of collective memory, so they are especially predestined to express common ideals and values that are the basis and rule of social life. Excluding them from society means to reject the past in which the present is rooted in the name of modernity devoid of memory. The elderly, thanks to their maturity and experience, can provide young people with advice and valuable lessons. The fragility of human existence, most clearly visible in old age, becomes in this perspective a reminder of the interdependence and the indispensable solidarity between different generations, as each person needs others and is enriched through the gifts and charisms of all."1

Many people, including the younger generation, understood the message of John Paul II. It shows that social initiatives are important, thanks to which elderly people should not only take care of their physical and intellectual abilities and develop relationships with others, but also contribute, giving their time, skills and experience necessary for the development of society. Thanks to Karol Wojtyla (his election to the Throne of Peter), an unexpected and, at the same time, spectacular phenomenon took place that people who listened to and accepted Wojtyla's teachings were called "John Paul II's generation". The JP2 generation includes different age groups. Among them are the present forty and fifty-yearolds who were entering their adulthood at the time when Cardinal Karol Wojtyla was elected Pope. Another group consists of thirty-year-olds, whose value system was based on the teachings of John Paul II. The "JP2 Generation" can

${ }^{1}$ List Ojca Świętego Do moich Braci i Sióstr - ludzi w podeszłym wieku, https://opoka. org.pl/biblioteka/W/WP/jan_pawel_ii/listy/do_starszych_01101999.html (25.06.2020). 
also include younger people - today's 2o-year-olds and teenagers, who identify with the timeless values conveyed in the teaching of John Paul II. Therefore, it is difficult to clearly explain this phenomenon.

It is worth remembering that the term "JP2 Generation" was not created in Poland and does not only apply to young people from our country. This term was born in France in 1997, after the World Youth Day in Paris. Today, 15 years after the death of the Polish Pope, it can be said that the pontificate of John Paul II was truly exceptional and valuable, and that the JP2 generation does exist. The authentic example of Karol Wojtyła, overwhelmed by diseases, age and undisguised physical suffering - who, nonetheless, is a Guide and Authority for young people - invariably deserves careful attention, analysis and interest from educators, sociologists, psychologists and representatives of other fields of science. $^{2}$

John Paul II's message gave rise to another shift in the relationship between old age and youth. In our civilization, culture and its institutions, symbols become dynamic, changeable and elusive. Permanent patterns, previously established institutions, authorities and established hierarchy are tested/verified on the evidence that they provide. Ideas, revolutions, values - appear, explode and... disappear. Some of the people keep adapting to changes and new requirements, others have a problem with it, and cannot keep up with a dynamically changing reality. An elderly person living in today's world may adopt various attitudes. These attitudes are generated by health, personality, education, social status and many other factors.

The positive aspects of modern senectitude include: universal retirement and pension security, better social conditions, improved health conditions, a more favorable cultural and educational situation, a higher level of education, access

${ }^{2}$ Integralna troska o chorego u kresu życia, eds. A. Bertman-Wierzchowska, W. Kochan, J. Stala, Kraków 2020, Wydawnictwo UJ; Rodzina w społeczeństwie - relacje i wyzwania, ed.s E. Osewska, J. Stala, Kraków 2019, Wydawnictwo naukowe UPJPII; Człowiek chory i umierający. Możliwości wsparcia i formy pomocy, ed. J. Stala, Kraków 2014, wydawnictwo UPJPII; Człowiek wobec bólu, cierpienia i śmierci, eds. J. Stala, N. Bravena, Kraków 2013, wydawnictwo UPJPII; Życie i śmierć. Wyzwania działalności charytatywnej, ed. J. Stala, Tarnów 2012, wyd. Polihymnia; J. Stala, Formation of Adult Lay Catholics for Commitment in the World, "The Person and the Challenges" 7 (2017) nr 2, pp. 93-106; J. Stala, Der Mensch als Person: Die bestimmende Grundlage für Johannes Paul II. in seinem Bild von der Familie, "The Person and the Challenges" 2 (2012) nr 2, pp. 41-59; D. Baturina, How to Protect Elderly Persons? Possibilities of Improving the Social Status of and Preventing Violence Towards Elderly Persons, "Bogoslovska Smotra" Vol. 91 (2021) Nr 1, pp. 177-144. 
to the media, universal recognition of human rights, a higher level of selfawareness and subjectivity, and greater mobility. The negative features of modern human life in old age include: unfavorable changes in families, one-generational family, having one child or childlessness, a large number of divorces, the disappearance of mental ties, the reign of the cult of youth, depriving the elderly of authority, negative stereotypes of old age (ageizm), secularization of social life, taboos related to death and transience, problems with managing the time of an extended life, physical and mental disability increasing with age, limiting independence, and finally the problems of most countries in the care and treatment of the constantly growing elderly population. Therefore, it is very important for seniors to remain active, including physical activity and involvement in both family and social life.

\section{The Autumn of life - what is senectitude?}

It is a complicated biological and psychological process. E. Trafiałek claims that "senectitude is a natural phase of life, following youth and maturity, crowning the dynamic aging process. Defined as the final third of life, it is associated with a decrease in the body's efficiency, loss of mobility, weakening of immune forces (biological and physiological senility), limitation of the ability to adapt to any changes, and in the socioeconomic context - often pauperization, loneliness (mental senility), the need to require assistance from others' the help of others (economic senility) and functioning on the margins of social life (social senility)."

A. Zych defines senility as (...$)$ the inevitable effect of aging, in which biologi$\mathrm{cal}$, mental and social processes start to interact synergistically with each other, leading to the violation of the biological and psychological balance without the possibility of counteracting, it; the final stage of aging. Senescence as the period of life following adulthood is a static concept, while aging as a process is a dynamic phenomenon. The beginning of senility is conventionally considered to be at 60 or 65 years of age, with death being the inevitable end of the said process. ${ }^{4}$

${ }^{3}$ E. Trafiałek, Starzenie się i starość. Wybór tekstów z gerontologii społecznej, Wszechnica Świętokrzyska, Kielce 2006, p. 269.

${ }^{4}$ A. Zych, Słownik gerontologii społecznej, Wydawnictwo Akademickie “Żak”, Warszawa 2001. 
M. Krawczyński puts it in yet another way - "senility is a natural and inevitable stage of life, in which significant changes occur in the physical, mental and social sphere of human functioning. Changes in the aging process appear at different stages of life. At the same time, along with involution processes, there are phenomena of compensation related to physiological activities and life experience. Old age should not be associated with a passive waiting for death or with death itself (the so-called road to death), but it has to be seen as the road leading to life."

It is a difficult task to precisely define senescence and its beginning. The fact is, as the years go by, the effects of aging become more and more visible.

\section{Positive aging and the role of physical and social activity}

Adaptation and preparation for old age include preventing its effects, but also providing seniors with a standard of living which is adequate to their needs. Although aging is irreversible, this process can be delayed. The rate of aging of people depends on many factors: lifestyle, individual and social conditions, health, character, habits, the feeling of being needed,, the physical and mental condition, etc. Therefore, it is necessary to activize the elderly in a broad sense. The changes that occur in the body as a result of aging do not bypass any of our body systems. Seniors suffer from cardiovascular diseases, diseases of the musculoskeletal system, and pains in the joints and spine, which limit their mobility and the possibility of an active life. In people over 50, these natural processes are very often combined with the negative effects of a sedentary lifestyle, being overweight and other physical neglect. Many people fall into a vicious cycle: they don't want to be physically active because they feel bad, and at the same time they feel bad because they don't exercise. Lack of physical activity and moderate exercise causes a decrease in physical efficiency, decreased muscle strength, problems with the joints and the circulatory system.

The concept of positive aging is primarily intended to prevent or delay the occurrence of diseases that are characteristic of senescence/senectitude. Scientists who are looking for methods to delay the aging processes now agree that physical activity is undoubtedly one of these methods. Physical activity, which

${ }^{5}$ W. Tłokiński, Słowo wstępne, in: M. Krawczyński, Wypetnianie starości-trening ku życiu, Gdańsk 1997, pp. 8-10. 
is moderate and adapted to the possibilities of each age, has a beneficial effect not only on muscles and joints, but also on the nervous system and other systems in the human body.

A frequently quoted definition of physical activity is the one by J. Barankiewicz. In this case, physical activity is tantamount to "undertaking various types of games, exercises and sports disciplines as part of active recreation, for pleasure, recreation and health, improving exercise capacity, gaining special fitness and physical skills, preventing the emergence of civilization diseases, increasing beneficial effects on the ability to work physically and mentally."

On the other hand, T. Wolańska defines physical recreation as all sports and tourist activities undertaken on their own initiative, in their free time, for the purpose of rest and pleasure. ${ }^{7}$ Physical activity is an extremely important element of human life. It plays an important role in maintaining health and fitness, and manifests itself, among others, in performing household activities, moving around, practicing sports and physical recreation, as well as in professional work, especially physical work. E. Kozdroń and B. Szatur-Jaworska believe that "physical activity, health and quality of life are closely related. The human body is built to move, so it requires regular physical activity to function optimally and to avoid disease."

Movement is essential for proper human development. The 2008 European Union (EU) Physical Activity Guidelines stated that, as a result of regular physical activity, the human body undergoes morphological and functional changes that can prevent or delay the onset of many diseases and improve the ability to exercise. With age, the possibilities of taking up physical activity are diminishing, and changes in lifestyle only intensify this phenomenon. As a result of technological progress in recent years, there has been a significant reduction in the amount of physical effort necessary to perform household duties, to move from place to place (cars, buses, metro), and even to take up recreational activities (including reaching people who organize physical

\footnotetext{
${ }^{6}$ J. Barankiewicz, Leksykon wychowania fizycznego i sportu szkolnego, Wydawnictwa Szkolne i Pedagogiczne, Warszawa 1998, p. 11.

T. Wolańska, Rekreacja ruchowa i turystyka, wyd. AWF, Warszawa 1989.

${ }^{8}$ E. Kozdroń, Kultura fizyczna - sport dla wszystkich, in: Strategie działania w starzejącym się społeczeństwie. Tezy i rekomendacje, ed. B. Szatur-Jaworska, Biuro Rzecznika Praw Obywatelskich, Warszawa 2012, pp. 63-72.
} 
activities). According to the available data, about 40 to $60 \%$ of the EU population lead a sedentary lifestyle. ${ }^{9}$

The leading role of physical activity is presented in the WHO International Classification of Functionalities. Physical activity has recreational (active leisure), preventive (for people at high risk of chronic diseases). therapeutic and rehabilitation (after an acute incident or to minimize symptoms of an advanced disease) applications.

WHO recommendations regarding physical activity for seniors are as follows:

1. At least 150 minutes of moderate intensity exercise per week or $75 \mathrm{~min}$ utes of high intensity exercise per week. Alternatively, it can be a combination of moderate and vigorous exercise. If possible, regular exercise every day is recommended.

2. It is advised that the effort to improve respiratory efficiency is performed in at least 10-minute intervals.

3. To increase one's health benefits, the duration of moderate exercise should be increased up to 300 minutes a week, or 150 minutes a week should be dedicated to strenuous physical activity. Alternatively, it can be a combination of moderate and substantial training.

4. Exercises that aim to strengthen the muscles, involving major muscle groups, should be done two or more times a week.

5. In case of poor physical condition, the use of strengthening exercises, three or more times a week, to help balance the body and prevent falls, is recommended.

6. If one's health condition does not allow the elderly person to follow the recommended dose of physical activity, it is recommended to stay as active as possible.

7. Physical activity can be carried out individually or in a group, with or without supervision.

8. Health training can have different benefits, e.g. stretching, strength training, sensorimotor training, resistance training.

9. Simple and intermediate forms of physical activity are recommended as well: walking, dancing, swimming, cycling, exercising in a chair or bed.

10. Playing should be the preferred form of activity - giving/getting pleasure from the exercises.

${ }^{9}$ https://ec.europa.eu/assets/eac/sport/library/policy_documents/eu-physical-activityguidelines-2008_pl.pdf (11.09.2019). 
In the opinion of the World Health Organization, active seniors experience less health deficits and have greater psychophysical efficiency, and thus the costs of health care incurred by individual countries are reduced. Regular activity contributes to the delay of dementia, Alzheimer's disease, cardiovascular disease and many other chronic diseases. Moreover, active seniors are people with greater ability and willingness to work, making a significant contribution to the development of society. ${ }^{10}$

Systematic physical activity, which is properly adapted to the particular state of health, in the form of, for example, physical recreation, has a very positive effect on the human body.

The following positive changes in the body can be observed under the influence of systematic physical activity, in both young adults and seniors (OR the elderly):

1. The physical efficiency of the organism increases, i.e. the ability to perform long, intense physical work. Muscles subjected to physical activity become thickened and improve their blood supply. Oxygen is used better during work, thus efficiency, strength, speed of muscle contraction, endurance and resistance to fatigue increases. It is worth emphasizing that if one does not perform strength-development exercises during recreational activities, the muscle mass will not increase.

2. The performance of the heart increases and blood pressure is lowered. This results in a more economical heart beat and greater energy reserves. After exercise, heart rate and blood pressure return to baseline levels faster than in non-exercising people. The arteries widen and strengthen.

3. The efficiency of lung ventilation is improved. The respiratory system works more efficiently - the vital capacity of the lungs increases, voluntary apnea is prolonged, which implies lower oxygen consumption and greater strength of the respiratory muscles. During exercise, breathing is regular, and after exercise, an efficient breathing process allows the rest of the body to return to normal more quickly.

4. The body weight and subcutaneous fat content decrease, and there are changes in the energy economy - metabolism increases, appetite

${ }^{10}$ W.J. Chodzko-Zajko, The World Health Organization Issues Guidelines For Promoting Physical Activity Among Older Persons, "Journal of Aging and Physical Activity" (1997) 5 (1), pp. 1-8. 
decreases, adipose tissue is reduced. Increased physical activity leads to changes in the secretion and function of hormones. For example insulin secretion during exercise is reduced later, reducing the likelihood of developing diabetes.

5. Exercise accelerates the conversion of cartilage to bone, thus supporting the growth process. The skeletal bone tissue becomes more stable and more resistant to injuries. Regular (and optimally matched to age) physical activity corrects posture defects and prevents the formation of deformations. Regular physical exercise combined with a diet rich in calcium and vitamin $\mathrm{D}$ has a positive effect on the degree of bone mineralization. There is also (anectodal) evidence of bone hypertrophy with these measures, such as changes in the shape, length and width of the bones.. Adequate bone formation is very important because it protects the skeleton against fractures and is also an important factor in the prevention of osteoporosis. By influencing the shape of the articular surfaces, physical activity leads to an increase in the range of motion of a given joint. The parameters of the elements building the joints will improve, including the flexibility and elasticity of joint capsules and ligaments. Movements in the joints are supported by the muscles, so it is important to keep the latter in good shape and constantly develop the entire motor system by regularly performing general development exercises. ${ }^{11}$

Similarly, J. Drabik cites the effects resulting from the above-mentioned changes, occurring thanks to systematic physical activity. These are:

1. endurance - physical performance:

- acceleration of the recovery process,

- lowering the risk of coronary heart disease and other cardiovascular diseases,

- reduction of excess body fat.

2. strength - increase in the functioning of motor capabilities and skills, guaranteeing safe lifting of a load:

- lower back pain reduction,

- increasing the ability to stay physically active during the day,

- muscular endurance - increase in the functional abilities and ability

${ }^{11}$ http://www.sosw.torun.pl/start_pliki/publikacje_pliki/Pozytywny\%20wplyw\%20 aktywnosci\%20fizycznej.pdf, (12.09.2019). 
to perform movements.

3. flexibility - increasing functional possibilities - freedom in making painless turns, bends, reduction of back pain. ${ }^{12}$

Exercise is also an effective treatment for ischemic heart disease, high blood pressure, obesity, diabetes, and more. It also prevents the formation of atherosclerosis, which can cause complications which are dangerous, especially for the elderly. In addition, systematic physical activity has a beneficial effect on memory and mental processes. The immunity of the elderly/seniors who exercise is also strengthened by stimulating the activity of lymphocytes and granulocytes during exercise. A. Jagier says simply: "systematic physical activity (health training) - consists in performing strictly defined physical exercises to counteract the aging process. ${ }^{\prime \prime 3}$ Therefore, despite the inability to achieve results comparable to a younger person, seniors still find many beneficial aspects in physical activity. The presentation of the possibility of seniors' participation in physical activity allows us to state that the multitude of forms, be it physical recreation or tourism, allows anyone interested to find an appropriate field for themselves to undertake a systematic exercise. Discussion of the effects of participation in physical activity, with the required limitations due to old age, would allow us to assume that the possibility of improving and maintaining one's health condition at a satisfactorily good level will arouse greater interest among seniors in this way of spending their free time.

The following general recommendations for physical activity in seniors are recommended by D. Szałtynis and T. Kochańczyk:

1. Breathing exercises should be a permanent addition to every major effort.

2. Overloading joints and strength exercises should be avoided.

3. It is advisable not to make any sudden movements, quick changes of position, or to switch from static to dynamic effort.

4. Any gear and equipment should be light, handy and aesthetic.

5. Postures that make breathing difficult, such as lying on the stomach, should be avoided.

6. Exercises or other forms of physical activity should be practiced sys-

${ }^{12}$ J. Drabik, Aktywność fizyczna w kształtowaniu zdrowia człowieka - korzyści i zagrożenia, "Wychowanie Fizyczne i Sport" (1999) nr 4, pp. 124-125.

${ }^{13}$ B. Stankiewicz, A. Majchrowski, W. Zukow, Nordic Walking as an alternative form of physical recreation, "Journal of Health Sciences" (2013) 3 (7), pp. 109-126. 
tematically/regularly.

7. In group activities, competition and escalation of negative emotions should be avoided. ${ }^{14}$

E. Kozdron also recommends consulting a doctor before starting any physical activity, and practicing self-control and self-assessment. ${ }^{15}$

According to WHO recommendations, seniors should take up physical activity at least three days a week to improve balance and prevent falls, and muscle strengthening exercises should be performed at least twice a week. If the elderly are unable to meet these recommendations due to medical contraindications related to chronic conditions, remember that, in reality, any activity is beneficial and it should be practiced as much as possible. Before the senior takes up the challenge of exercise, it is necessary to consult a doctor to adjust the activity to the state of health and thanks to it, improve, not overstrain, one's condition. Movement also relaxes, reduces stress, improves the quality of sleep, develops memory, concentration, attention, and removes the prospect of senile infirmity. Physical activity in a group improves social relations and makes it possible to make new friends. It is an opportunity to fulfill social roles, broaden thought horizons, and raise self-esteem. ${ }^{16}$

The major issue of seniors, especially those living in smaller towns, is that they do not show much interest in physical activity, although it is not excluded by their age, or often by their life situation. Specialists recommend such forms of tourism and recreation, the common denominator of which is increasing endurance and long-term performance of cyclical movements at an average pace. This means walking, cycling, canoeing, cross-country skiing and swimming. According to $\mathrm{H}$. Szwarc, the forms of qualified tourism should be implemented, in the first place, according to the above-mentioned assumptions. J. Hajdukiewicz even offers mountain tourism connected with communing with nature. Despite many objective and subjective dangers behind these disciplines, they create an inexhaustible source of aesthetic experiences and give broadly understood

${ }^{14}$ A. Łysak, A. Walentukiewicz, J. Drabik, A. Dąbrowski, R. Rowiński, Aktywność fizyczna i niektóre jej uwarunkowania w populacji seniorów województwa pomorski, "Hygeia Public heath" (2014) 49 (3), pp. 549-553.

${ }^{15}$ K. Bogus, E. Borowiak, T. Kostka, Otyłość i niska aktywność ruchowa jako ważne czynniki determinujące jakość życia osób starszych, "Geriatria” (2008) 2, pp. 116-120.

${ }^{16}$ E. Miszczak, Aktywność seniorów sposobem przeciwdziałania negatywnym skutkom procesu starzenia się, in: Jakość życia seniorów w XXI wieku: ku aktywności, eds. D. Kałuża, P. Szukalski, wyd. Biblioteka, Łódź 2010, pp. 27-32. 
satisfaction, which is important both for improving the physical and mental health of the elderly. T. Łobożewicz mainly suggests hiking in the form of trips of various lengths. As far as recreational activities are concerned, attention should be focused on individual and group gymnastics, exercise games, recreational games and outdoor activities such as running and orienteering marches. ${ }^{17}$ However, it should be remembered that every form of tourism and recreation taken up by an elderly person, should be adapted to their psychophysical abilities. The basic task of an elderly person is to adapt to the changing living conditions and to modify them to their own needs that change with age. Maintaining high physical, mental and social activity is one of the factors predicting a longer life expectancy, it enables older people to maintain autonomy and independence. Raising the level of knowledge about the benefits of a healthy lifestyle requires taking actions aimed at removing barriers preventing the elderly from actively participating in sport.

\section{The reasons for the inactivity of seniors in Poland}

It is necessary to consider the reasons for the low level of physical activity of older people in Poland, since the health-benefit importance of activity and moderate exercise is commonly emphasized. Cultural factors are especially mentioned among the reasons. In Polish culture, there is a shortage of traditions that would favor participation in physical culture. Recently, the atmosphere of reluctance towards physical activity in society has been breaking down. Old habits are gradually eliminated. It is a thing of the past to equate physical activity undertaken in free time with typical physical work, which was often the reason for passive rest. Nevertheless, changes in the mentality of Poles are still unsatisfactory and it is necessary to cultivate and recommend physical recreation with great emphasis, and to systematically accustom people of all ages to sports. Other reasons for low levels of activity are intellectual barriers, i.e. all obstacles caused by a misinterpretation of the meaning of movement - the belief that the regeneration of strength is primarily achieved through passive rest. Moreover, the dissemination of knowledge

\footnotetext{
17 A. Łysak, A. Walentukiewicz, J. Drabik, A. Dąbrowski, R. Rowiński, Aktywność fizyczna i niektóre jej uwarunkowania w populacji seniorów województwa pomorskiego, "Hygeia Public Heath" (2014) 49(3), pp. 549-553.
} 
about recreational exercises and their positive effects is insufficient. It also happens that seniors themselves limit their own physical activity due to the misconception that old people do not play sports. Seniors also indicate poor fitness, health problems, fear of being ridiculed, public disapproval as well as not noticing the relationship between health and physical activity and the resulting benefits, as the reasons preventing them from undertaking physical activity. Older people, due to their age, health condition or financial situation, also face a maladjustment of sports and recreational offers. There are also significant economic barriers resulting from the poor financial situation and living conditions of seniors, such as high fees for some forms of physical activity (swimming pool, gym, fitness, tennis, etc.). The above-mentioned barriers are the main determinants of low physical activity among seniors. Concerns are also associated with the possibility of fatigue, injury, or accidents. In this context, the difficult access by the elderly to doctors and physiotherapists is not without significance. The fear of making new friends is also important. This can effectively discourage people from undertaking physical recreation or tourism in organized forms, in which a group of unknown people takes part. Another problem is being ashamed of their body, which would have undergone changes related to the aging process. Older people do not want to expose their "unsightly" appearance through contacts with other people, often younger who, in their opinion, are "prettier".

The incentives for older people to making a decision to start exercise is often meeting with people who will competently encourage them, and for them to realize the benefits of moderate exercise. Activities that start under the care of specialists who not only individually select a set of exercises, but will also accompany the senior at every stage of their performance, are a great start for taking up the challenge of regular exercises. A good physical activity program for seniors should contain three basic elements: endurance exercises, strength exercises, and stretching, balance and coordination exercises. Regular exercise will not only have a positive effect on the well-being of the senior, but can also alleviate symptoms and even the course of chronic diseases. Patients with musculoskeletal disorders will also notice that regular exercise helps them to cope better with the pain. Changing the lifestyle from inactive to active always brings benefits - regardless of the age and health of the individual. As $\mathrm{H}$. Zdebska claims: "The physical activity of older people can therefore be perceived as a disinterested disconnected act, the value of which lies in the fact that it gives great satisfaction from the fact that it is structured this way and not otherwise, 
allowing the subjects participating in it to discover the meanings of and values that cannot be found elsewhere."18

Physical exercise for the elderly should be simple, enjoyable and as beneficial as possible. Experts emphasize that when starting the adventure of doing physical activity, it is worth starting with taking a walk. Regular walks, even when slow and lasting a dozen or so minutes, can make the senior feel better not only physically but also mentally, after just two weeks. Swimming is also an exercise recommended by researchers for the elderly. It is an activity that stimulates the action of all muscle groups (without overloading the joints), and also improves respiratory efficiency, oxygenating the body and accelerating metabolism. If swimming does not seem attractive to seniors, and their health allows them to do so, water aerobics is definitely recommended. Conducted under the supervision of an experienced trainer, in a group dedicated to the elderly, it will provide a positive dose of exercise and energy. Many fitness clubs also offer special group and individual classes with the words "gold", "senior" or " $50+$ " in the description of the course.. There are many possibilities and it is important to choose the physical activity adapted to the needs and preferences of the person doing the exercise.

Importantly, regular exercise increases the concentration of significant neurotransmitters, such as dopamine, serotonin, and norepinephrine. The increase in dopamine levels helps to improve memory and the ability to absorb new information. Serotonin improves the ability to receive information and improves mood. Norepinephrine affects concentration, memory, and the speed of information processing. The concentration of all these substances increases immediately after exercise. This is why, after physical activity, one can feel an improvement in attention, mood and calmness. The use of regular exercise in older people increases muscle mass, improves flexibility, strength and motor coordination, which prevents not only osteoporosis, but also other diseases. Moreover, Kozieł and Trafiałek showed that seniors undertaking physical activity assessed the quality of life, independence and social functioning to a higher degree compared to those who are physically inactive. ${ }^{19}$

${ }^{18}$ H. Zdebska, Aksjologiczny wymiar aktywności fizycznej w grupie wiekowej 50+, in: Aktywność fizyczna i społeczna osób trzeciego wieku, eds. J. Nowocień, K. Zuchora, Warszawa 2012, p. 242.

${ }^{19}$ D. Kozieł, K. Trafiałek, Kształcenie na Uniwersytetach Trzeciego Wieku a jakość życia seniorów, "Gerontologia Polska" (2007) 15 (3), pp. 104-108. 


\section{Ending}

Senility certainly takes something away, but also gives a lot. The profit and loss account largely depends on the person. Nowadays, the aging process is slowing down; more and more attention is being given to active, optimal, successful, positive, productive, and happy aging. Aging can be as good, rewarding, and successful as any other phase in life.

Old age is the final stage of life, but also the result of previous life experiences. Awareness of these experiences and their educational impact is an important, though not the only, element in successful senescence. The main component of successful senility is the acceptance of oneself and one's fate, shaped permanently throughout life, and resulting from a mature affirmation of life. Successful senescence most often results from the previous life phases. We reach old age by living. We have many years to learn how to live well in old age. In this context, senility should not surprise us. For the individual, dealing with old age is primarily dealing with overcoming one's own fears, limitations and stereotypes. It is the activation of factors that motivate towards creative, and innovative/inventive behaviour.

It is a fact that, physical activity and its direct, positive impact on people's quality of life, along with the belief that they are needed by the family and society, are among the most important factors for peaceful and happy aging.

\section{Bibliography}

Barankiewicz J., Leksykon wychowania fizycznego i sportu szkolnego, Wydawnictwa Szkolne i Pedagogiczne, Warszawa 1998.

Baturina D., How to Protect Elderly Persons? Possibilities of Improving the Social Status of and Preventing Violence Towards Elderly Persons, "Bogoslovska Smotra" Vol. 91 (2021) Nr 1, pp. 177-144.

Bogus K., Borowiak E., Kostka T., Otyłość i niska aktywność chowa jako ważne czynniki determinujące jakość życia osób starszych, Geriatria 2008.

Chodzko-Zajko W.J., The World Health Organization Issues Guidelines For Promoting Physical Activity Among Older Persons, "Journal of Aging and Physical Activity" (1997), pp. 1-8.

Człowiek chory i umierający. Możliwości wsparcia i formy pomocy, ed. J. Stala, Kraków 2014, wydawnictwo UPJPII.

Człowiek wobec bólu, cierpienia i śmierci, ed. J. Stala, N. Bravena, Kraków 2013, wydawnictwo UPJPII. 
Drabik J., Aktywność fizyczna w kształtowaniu zdrowia człowieka - korzyści i zagrożenia, "Wychowanie Fizyczne i Sport" (1999) nr 4, pp.124-125.

Górski J., Fizjologiczne podstawy wysiłku fizycznego, Wydawnictwo lekarskie PZWL, Warszawa 2006.

http://www.sosw.torun.pl/start_pliki/publikacje_pliki/Pozytywny\%20wplyw\%20aktywnosci\%20fizycznej.pdf (12.09.2019).

https:/ec.europa.eu/assets/eac/sport/library/policy_documents/eu-physical-activityguidelines-2008_pl.pdf (11.09.2019).

https://opoka.org.pl/biblioteka/W/WP/jan_pawel_ii/listy/do_starszych_01101999.html (25.06.2020).

Integralna troska o chorego u kresu życia, eds. A. Bertman-Wierzchowska, W. Kochan, J. Stala, Kraków 2020, Wydawnictwo UJ.

Kozdroń E., Kultura fizyczna - sport dla wszystkich, in: Strategie działania w starzejacym się społeczeństwie. Tezy i rekomendacje, ed. B. Szatur-Jaworska, Biuro Rzecznika Praw Obywatelskich, Warszawa 2012, p. 63.

Kozieł D., Trafiałek K., Kształcenie na Uniwersytetach Trzeciego Wieku a jakość życia seniorów, "Gerontologia Polska" (2007) 15(3), pp. 104-108.

Łysak A., Walentukiewicz A., Drabik J., Dąbrowski A., Rowiński R., Aktywność fizyczna i niektóre jej uwarunkowania w populacji seniorów województwa pomorskiego, “Hygeia Public Heath" (2014) 49(3), pp. 549-553.

Miszczak E., Aktywność seniorów sposobem przeciwdziałania negatywnym skutkom procesu starzenia się, in: Jakość życia seniorów w XXI wieku: ku aktywności, eds. D. Kałuża, P. Szukalski, Wyd. Biblioteka, Łódź 2010, pp. 27-32.

Rodzina w społeczeństwie - relacje i wyzwania, eds. E. Osewska, J. Stala, Kraków 2019, Wydawnictwo naukowe UPJPII.

Stala J., Der Mensch als Person: Die bestimmende Grundlage für Johannes Paul II. in seinem Bild von der Familie, "The Person and the Challenges" 2 (2012) nr 2, pp. 41-59.

Stala J., Formation of Adult Lay Catholics for Commitment in the World, "The Person and the Challenges" 7 (2017) nr 2, pp. 93-106.

Stankiewicz B., Majchrowski A., Zukow W., Nordic Walking as an alternative form of physical recreation, "Journal of Health Sciences" (2013) 3(7), pp. 109-126.

Trafiałek E., Starzenie się i starość. Wybór tekstów z gerontologii społecznej, Wszechnica Świętokrzyska, Kielce 2006.

Wolańska T., Rekreacja ruchowa i turystyka, Wyd. AWF, Warszawa 1989.

Zdebska H., Aksjologiczny wymiar aktywności fizycznej w grupie wiekowej 50+, in: Aktywność fizyczna i społeczna osób trzeciego wieku, eds. J. Nowocień, K. Zuchora, Warszawa 2012, p. 242.

Zych A., Leksykon gerontologii, Oficyna Wydawnicza "Impuls”, Kraków 2007.

Życie i śmierć. Wyzwania działalności charytatywnej, red. J. Stala, Tarnów 2012, wyd. Polihymnia. 